\title{
MODEL SINEKTIK DALAM PEMBELAJARAN PENGUKURAN WAKTU UNTUK MENINGKATKAN KREATIVITAS SISWA SEKOLAH DASAR Deti Rostika*)
}

\section{Abstrak}

Model synectics merupakan salah satu model pembelajaran yang dirancang untuk mengembangkan kreativitas siswa. Pemecahan masalah memerlukan penelitian secara ilmiah, dan sekaligus memerlukan kreativitas, baik dalam proses maupun dalam cara-cara pemecahan. Ada dua strategi atau model pembelajaran yang mendasari prosedur sinektik, yaitu Strategi Pertama: Menciptakan sesuatu yang baru. Strategi ini dirancang untuk mengenal keanehan, akan membantu para siswa memahami masalah, ide, atau produk dalam sesuatu yang baru yang akhirnya memperjelas kreatif. Strategi Kedua: Memperkenalkan keanehan. Strategi ini dirancang untuk membuat sesuatu yang baru, ide-ide yang tidak dikenal akan lebih berarti, kita melaksanakannya dengan analogi yang telah dikenal siswa.

Pengukuran secara tradisional dipasangkan dengan geometri dalam kurikulum, tetapi pengukuran sebenarnya lebih dekat dengan topic matematika lainnya. Agar siswa dapat meluangkan waktu lebih banyak untuk terlibat dalam kegiatan pengukuran secara seksama, pengukuran sebaiknya diintegrasikan sepanjang kurikulum matematika dan juga kurikulum ilmu pengetahuan alam. Dalam tulisan ini akan dicontohkan bagaimana mengajarkan pengukuran menggunakan model sinektik.

\section{Kata Kunci Model Sinektik, Pembelajaran Pengukuran Waktu, Kreativitas}

\section{A. Pendahuluan}

Dalam kehidupan modern perubahan terjadi secara cepat, sehingga menimbulkan banyak masalah. Masalah tersebut ada yang sederhana, dan ada yang kompleks. Pemecahan masalah memerlukan penelitian secara ilmiah, dan sekaligus memerlukan kreativitas, baik dalam proses maupun dalam cara-cara pemecahan. Siswa perlu dididik untuk menjadi terampil memecahkan masalah, dan kreatif dalam memecahkan masalah. Model sinektic merupakan salah satu model pembelajaran yang dirancang untuk mengembangkan kreativitas. Kreativitas hanya muncul bila seseorang terbiasa dengan aktivitas. Oleh karena itu model synectics cocok untuk menciptakan kondisi yang mendorong timbulnya cara belajar aktif dan sekaligus kreatif. 
Model synectics merupakan salah satu model pembelajaran yang dirancang untuk mengembangkan kreativitas siswa. Hal ini sesuai dengan pendapat William J.J. Gordon (Sumantri M,1998/1999:85) bahwa:

Synectics dilandasi oleh empat gagasan yang menantang pandangan konvensional, yaitu tentang kreativitas. Pertama, kreativitas penting dalam kegiatan sehari-hari. Kedua, proses kreatif bukanlah hal misterius, tetapi dapat dijelaskan dan mungkin saja melatih orang-orang secara langsung untuk meningkatkan kreativitasnya. Ketiga, temuan kreatif ditandai oleh proses intelektual. Keempat, penemuan individu dan kelompok adalah sama melalui berpikir kreatif.

Gordon menekankan kreativitas sebagai bagian dari kegiatan harian dan kehidupan senggang. Modelnya dirancang untuk meningkatkan kemampuan memecahkan masalah, pengungkapan/ekspresi yang kreatif, empati, dan tilikan terhadap hubungan social. Bagi kebanyakan orang kreativitas terkait dengan seni, sedangkan dalam sains ditekankan penemuan. Hal ini sesuai juga dengan pendapat Moedjiono (1992/1993: 148) bahwa "synectics adalah pola belajar mengajar yang dirancang untuk melatih siswa mengembangkan (1) keterampilan memecahkan masalah secara kreatif, dan (2) kreativitas pribadi. “ Model synectics juga cocok untuk mengembangkan rasa simpati, dan kemampuan membuat tilikan dalam hubungan social.

Gordon (Joyce B, 2009:252) menguraikan :sinektik berdasarkan empat gagasan yang sekaligus juga menyaingi pandangan-pandangan konvensional tentang kreativitas.” Pertama, kreativitas penting dalam kegiatan sehari-hari. Kita seringkali mengasosiasikan proses kreatif dengan usaha mengkaji secara besarbesaran bidang seni atau music, dan mungkin dengan inovasi baru yang lebih hebat. Sedangkan Gordon menekankan kreativitas sebagai bagian dari kerja sehari-hari dan kehidupan waktu senggang. Modelnya dirancang untuk meningkatkan kapasitas pemecahan masalah., ekspresi kreatif, empati dan wawasan kedalam relasi-relasi social. Dia juga menekankan bahwa makna gagasan dapat ditingkatkan melalui aktivitas kreatif dengan cara melihat sesuatu dengan lebih kaya.

Kedua, proses kreatif tidak selamanya misterius, tetapi dapat dideskripsikan, bisa melatih siswa untuk langsung meningkatkan kreativitas 
mereka. Biasanya kreativitas dipandang sebagai kapasitas yang misterius, intrinsic, pribadi yang bisa saja dirusak, jika prosenya dijajaki terlalu dalam. Sebaliknya Gordon percaya bahwa jika individu-individu memahami dasar proses kreatif, mereka dapat belajar menggunakan pemahaman tersebut untuk meningkatkan kreativitas saat mereka hidup dan bekerja, secara independen maupun sebagai anggota suatu masyarakat/kelompok. Pandangan Gordon bahwa kreativitas ditingkatkan oleh analisis secara sadar membuat dia mampu mendeskripsikan kreativitas tersebut dan membuat prosedur-prosedur latihan yang dapat diaplikasikan di sekolah dan lembaga-lembaga lain.

Ketiga, penemuan atau inovasi yang dianggap kreatif sama rata di semua bidang seni, sains, teknik, dan ditandai oleh proses intelektual yang sama. Gagasan ini berbeda dengan kepercayaan umum. Sebenarnya bagi banyak orang kreativitas terbatas pada seni. Dalam teknik dan sains, kreativitas begitu mudahnya disebut dengan nama baru: penemuan atau inovasi. Padahal Gordon menyatakan bahwa hubungan antara pemikiran generative dalam seni dan sains sangat kuat.

Keempat, bahwa penemuan (pola pikir kreatif) individu maupun kelompok tidak berbeda. Individu-individu dan kelompok-kelompok menciptakan gagasangagasan dan hasil-hasilnya dalam ragam yang sama. Hal ini juga berbeda dengan sikap/pendirian banyak orang bahwa kreativitas selalu dianggap sebagai pengalaman pribadi secara intens, dan tidak dapat dibagi atau dilakukan secara berkelompok.

Beberapa proses sinektik tertentu dikembangkan dari beberapa asumsi tentang psikologi kreativitas (the psychology of creativity). Asumsi pertama, dengan membawa proses kreatif menuju kesadaran dan dengan mengembangkan bantuan-bantuan eksplisit menuju kreativitas, kita dapat secara langsung meningkatkan kapasitas kreatif secara individu maupun kelompok.

Asumsi yang kedua adalah bahwa komponen emosional lebih penting daripada intelektual, irasional lebih penting dari pada rasional. Kreativitas merupakan pengembangan pola-pola mental baru. Interaksi yang tidak masuk akal menyisakan ruang bagi pemikiran yang terus menerus yang dapat menunutun 
pada kondisi mental dimana banyak gagasan-gagasan baru muncul. Kondisi analogistik merupakan lingkungan mental yang terbaik dalam mengeksplorasi dan mengembangkan gagasan-gagasan, tetapi bukanlah tahap membuat keputusan.gordon tidak menilai kecerdasan linear, dia berasumsu bahwa logika digunakan untuk membuat keputusan dan kompetensi teknik digunakan untuk menyusun gagasan di berbagai bidang. Akan tetapi, dia percaya bahwa kreativitas pada dasarnya merupakan proses emosional, yang mensyaratkan unsure-unsur irasionalitas dan emosi untuk meningkatkan proses intelektual. Banyak pemecahan masalah yang rasional dan cerdas, tetapi dengan menambah hal-hal yang tidak irasional, kita akan dapat menciptakan kemungkinan-kemungkinan lain yang dapat kita gubnakan untuk meningkatkan gagasan-gagasan segar.

Asumsi ketiga adalah bahwa unsure-unsur emosional, irasional harus dipahami dalam rangka meningkatkan kemungkinan sukses dalam situasi pemecahan masalah. Dengan kata lain, analisis terhadap proses irasional dan emosional tertentu dapat membantu individu dan kelompok untuk meningkatkan kreativitas mereka dengan menggunakan irasionalitas secara konstruktif.aspekaspek irasional dapat dipahami dan dikontrol secara sadar. Pencapaian control ini, melalui penggunaan metafora dan analogi secara seksama, merupakan objek sinektik.

Aktivitas metafora dalam sinektik, kreativitas menjadi proses yang dapat dilaksanakan secara sadar. Metafora-metafora membangun hubungan perumpamaan, perbandingan satu objek atau gagasan dengan objek atau gagasan lain, dengan cara menukarkan posisi keduanya. Hal ini sesuai dengan pendapat Dahlan (1984:89) bahwa "metafora-metafora membentuk hubungan persamaan, membedakan objek atau ide yang satu dengan yang lainnya dengan mempergunakan pengganti.” Objek pengganti ini langsung mengilhami proses kreatif dengan cara menghubungkan sesuatu yang telah dikenal dengan sesuatu yang belum dikenal.

Metafora memperkenalkan konsep jarak antara siswa dengan objek atau subyek lain, dan mendorong berpikir orisinil. Sebagai contoh, misalnya siswa disuruh memikirkan pelajarannya sebagai sebuah sepatu tua atau sebagai suatu 
sungai. Sebenarnya kita telah menyediakan sebuah struktur, sebuah metafora, dimana siswa dapat memikirkan segala sesuatu yang telah dikenalnya melalui sesuatu cara yang baru. Sebaliknya, kita dapat meminta siswa untuk memikirkan tentang topic baru, katakanlah tubuh manusia, dengan cara yang lama, yaitu dengan cara meminta siswa membandingkannya dengan system transportasi. Aktivitas metaforik membantu para siswa untuk dapat menghubungkan ide-ide dari hal-hal yang yang telah dikenalnya menuju ke hal-hal baru atau dari suatu perspektif baru menuju ke hal yang telah dikenal. Model sinektik mempergunakan aktivitas metaforik yang terencana, memberikan struktur langsung dimana individu bebas mengembangkan imajinasi dan pemahamannya kedalam aktivitas sehari-hari. Ada tiga tipt analogi yang dipergunakan sebagai dasar latihan sinektik, yaitu analogi personal (personal analogy), analogi langsung (direct analogy), dan konflik padat atau menekankan pertentangan (compressed conflict).

\section{B. Model Pembelajaran Sinektik}

\section{Tahap-tahap Model}

Ada dua strategi atau model pembelajaran yang mendasari prosedur sinektik, yaitu Strategi Pertama: Menciptakan sesuatu yang baru. Strategi ini dirancang untuk mengenal keanehan, akan membantu para siswa memahami masalah, ide, atau produk dalam sesuatu yang baru yang akhirnya memperjelas kreatif. Strategi Kedua: Memperkenalkan keanehan. Strategi ini dirancang untuk membuat sesuatu yang baru, ide-ide yang tidak dikenal akan lebih berarti, kita melaksanakannya dengan analogi yang telah dikenal siswa.

Meskipun kedua strategi ini sama-sama mengikuti ketiga analogi, tetapi onjek, tahapan dan prinsip reaksinya berbeda. Kita menghubungkan strategi pertama dengan strategi yang kedua. Strategi pertama membantu para siswa melihat sesuatu yang dikenalnya, melalui sesuatu yang tidak dikenal dengan mempergunakan analogi-analogi untuk menciptakan konsep jarak. Kecuali dalam langkah yang terakhir, para siswa kembali ke masalah yang sebenarnya, dengan tidak memberikan perbedaan yang berarti. Tujuan strategi ini untuk dapat mengembangkan suatu pemahaman baru, misalnya terhadap gerak-gerik atau 
tingkah laku seseorang, perencanaan suatu kota, pemecahan masalah-masalah hubungan social antara lain pemogokkan, perkelahian antar siswa, konsentrasi belajar yang lebih baik, dan sebagainya. Peranan guru hanya memberikan bimbingan pada tahap awal dan pada tahap akhir kegiatan.

\section{Sintak Model Sinektik}

\begin{tabular}{|l|l|}
\hline \multicolumn{2}{|l|}{ TAHAPAN STRATEGI PERTAMA } \\
\hline $\begin{array}{l}\text { Tahap Pertama: } \\
\text { Mendeskripsikan kondisi saat } \\
\text { ini }\end{array}$ & $\begin{array}{l}\text { Tahap Kedua: Analogi } \\
\text { Langsung }\end{array}$ \\
\hline $\begin{array}{l}\text { Guru menyuruh siswa untuk } \\
\text { mendeskripsikan situasi atau suatu } \\
\text { topic yang mereka lihat saat ini. }\end{array}$ & $\begin{array}{l}\text { Para siswa mengemukakan } \\
\text { analogi langsung, salah satu } \\
\text { diseleksi dan selanjutnya } \\
\text { dikembangkan. }\end{array}$ \\
\hline Tahap Ketiga: Analogi Personal & $\begin{array}{l}\text { Tahap Keempat: Penekanan } \\
\text { Konflik }\end{array}$ \\
\hline $\begin{array}{l}\text { Para siswa menjadi analogi yang } \\
\text { diseleksinya pada fase kedua. }\end{array}$ & $\begin{array}{l}\text { Berdasarkan fase kedua dan } \\
\text { ketiga, para siswa } \\
\text { mengemukakan beberapa konflik } \\
\text { dan dipilih salah satu. }\end{array}$ \\
\hline Tahap Kelima: Analogi Langsung & $\begin{array}{l}\text { Tahap Keenam: Meninjau tugas } \\
\text { yang sebenarnya. }\end{array}$ \\
\hline $\begin{array}{l}\text { Para siswa mengembangkan dan } \\
\text { menyeleksi analogi langsung } \\
\text { lainnyaberdasarkan konflik tadi. }\end{array}$ & $\begin{array}{l}\text { Guru menyuruh para siswa } \\
\text { meninjau kembali tugas atau } \\
\text { masalah yang sebenarnya dan } \\
\text { menggunakan analogi yang } \\
\text { terakhir dan/atau masuk pada } \\
\text { pengelaman sinektik. }\end{array}$ \\
\hline
\end{tabular}

Bagan 1: Tahapan Untuk Menciptakan Sesuatu Yang Baru

Strategi kedua, memperkenalkan keanehan, memberikan pemahaman para siswa untuk menambah dan memperdalam hal-hal yang baru atau materi yang sulit. Metafora dipergunakan untuk keperluan penganalisaan, bukan untuk menciptakan konsep jarak seperti halnya pada siswa strategi pertama. Misalnya guru memberikan konsep tentang kebudayaan pada siswa-siswanya. Dengan analogi-analogi yang telah dikenalnya (misalnya kompor atau rumah). Para siswa memberikan batasan karakteristiknya dan disempurnakan dalam konsep. Strateginjya jelas analitis dan konvergensi. Para siswa selalu mempunyai pilihan 
antara kejelasan karakteristik subyek yang dikenalnya dan membedakannya dengan karakteristik yang tidak dikenalnya.

\begin{tabular}{|l|l|}
\hline TAHAPAN STRATEGI KEDUA \\
\hline $\begin{array}{l}\text { Tahap Pertama: Input tentang } \\
\text { keadaan yang sebenarnya }\end{array}$ & Tahap Kedua: Analogi Langsung \\
\hline $\begin{array}{l}\text { Guru menyajikan informasi } \\
\text { tentang suatu topic yang baru }\end{array}$ & $\begin{array}{l}\text { Guru mengusulkan analogi } \\
\text { langsung dan menyuruh siswa } \\
\text { menjabarkannya. }\end{array}$ \\
\hline Tahap Ketiga: Analogi Personal & $\begin{array}{l}\text { Tahap Keempat: Membedakan } \\
\text { Analogi }\end{array}$ \\
\hline $\begin{array}{l}\text { Guru menyuruh siswa menjadi } \\
\text { analogi langsung }\end{array}$ & $\begin{array}{l}\text { Para siswa menjelaskan dan } \\
\text { menerangkan kesamaan antara } \\
\text { materi yang baru dengan analogi } \\
\text { langsung }\end{array}$ \\
\hline $\begin{array}{l}\text { Tahap Kelima: Menjelaskan } \\
\text { Perbedaan }\end{array}$ & Tahap Keenam: Penjelajahan \\
\hline $\begin{array}{l}\text { Para siswa menjelaskan mana } \\
\text { analogi-analogi yang tidak sesuai }\end{array}$ & $\begin{array}{l}\text { Para siswa menjelaskan kembali } \\
\text { kebenaran topic dengan batasan- } \\
\text { batasan mereka. }\end{array}$ \\
\hline Tahap Ketujuh: Membangkitkan Analogi \\
\hline $\begin{array}{l}\text { Para siswa memberikan analogi sendiri secara langsung dan } \\
\text { menjelajahi persamaan dan perbedaannya. }\end{array}$ \\
\hline
\end{tabular}

Bagan 2: Tahapan Untuk Memperkenalkan Keanehan

\section{Sistem Sosial}

Model dirancang dengan layak, dengan mengajukan rangkaian pedoman dalam mekanisme pelaksanaannya, agar dapat membantu siswa mampu memproses mental mereka. Bagaimanapun juga para siswa dibebaskan dalam membuka dan menutup diskusi. Bentuk-bentuk kerjasama dalam berfantasi, intelektual serta emosional, sama-sama penting untuk mendapatkan setting , kreatif, atau problem solving. Keuntungannya bagi siswa bersifat internal maksudnya para siswa memperoleh kepuasan dan kesenangan dalam aktivitas belajarnya.

\section{Prinsip Reaksi}

Guru mencatat kedalaman pola berpikir yang menetap dan tampak pada individu, dan mengusahakan membangkitkan kemampuan psikis siswa untuk merespon kreatif. Selanjutnya guru harus memanfaatkan hal-hal yang bersifat 
tidak rasional untuk mendorong keengganan kata hatinya, mengemukakan sesuatu yang tidak relevan, fantasi, symbol-simbol dan sebagainya sebagai alat proses berpikir. Guru harus menerima semua respon siswa, agar mereka merasa diterima untuk lebih mengembangkan ekspresi kreatifnya. Dalam strategi kedua, sejak awal, siswa dibimbing untuk menganalisis. Guru menjelaskan dan meringkas kemungkinan aktivitas belajar siswa dan bertingkah laku problem solving oleh siswa.

\section{Sistem Pendukung}

Dalam prosedur sinektik, kelompok membutuhkan semua fasilitas melalui seorang pemimpin yang kompeten. Dalam hubungannya dengan masalah-masalah yang membutuhkan laboratorium, mereka membutuhkan peralatan-peralatan untuk dapat dipergunakan dalam keperluan praktek yang lebih berdaya guna dan member manfaat pada siswa.

\section{Aplikasi}

Sinektik dirancang untuk meningkatkan kreativitas individu dan kelompok. Berikut diuraikan aplikasi sinektik yakni sebagai berikut.
a. Manfaat sinektik dalam kurikulum
b. Pengembangan kreasi menulis
c. Menjelajahi masalah-masalah social
d. Problem solving
e. Pengembangan kreasi, rencana atau produk
f. Memperluas perspektif tentang suatu konsep

\section{Dampak Instruksional dan Pengiring}

Model sinektik berisikan elemen-elemen yang kuat untuk pembelajaran dan nilai-nilai social. Proses kreatif dapat dikomunikasikan dan dapat dikembangkan melalui latihan-latihan. Sinektik dikembangkan Gordon tidak hanya untuk keperluan pengembangan kemampuan kreatif yang bersifat uum, tetapi juga untuk mengembangkan respon kreatif.

Gordon akhirnya merasa yakin bahwa energy kreatif akan mendorong kreativitas dan dipergunakan kelompok untuk membangkitkan enegi yang memungkinkan partisipasi lebih bebas dan berperan. Metode sinektik dirancang 
untuk meningkatkan kreasi individu dan kelompok. Secara implicit, model ini sebenarnya menyenangkan. Partisipasi dalam suatu kelompok sinektik tentang kreatif merupakan andil yang unik membantu pengembangan pemahaman interpersonal dan rasa kemasyarakatan; menyebabkan yang bersangkutan dapat saling memahami satu dengan yang lainnya, menyadari kelemahan dan kebebasannya dalam berbagai persepsi anggota kelompok. Dasar satu-satunya aktivitas kelompok sinektik adalah kesederhanaan berpikir dan suasana yang menyenangkan yang mendorong kemantapan sebagian besar partisipan yang takut atau malu.

\section{Pembelajaran Pengukuran Waktu Melalui Model Sinektik}

\section{Konsep Pengukuran}

Pengukuran secara tradisional dipasangkan dengan geometri dalam kurikulum, tetapi pengukuran sebenarnya lebih dekat dengan topic matematika lainnya. Agar siswa dapat meluangkan waktu lebih banyak untuk terlibat dalam kegiatan pengukuran secara seksama, pengukuran sebaiknya diintegrasikan sepanjang kurikulum matematika dan juga kurikulum ilmu pengetahuan alam.

Konsep pengukuran sudah banyak digunakan oleh siswa, baik siswa kelas rendah maupun siswa kelas tinggi. Seperti misalnya pernyataan-pernyataan yang sering dilontarkan siswa: “saya lebih tinggi dari dia”, besar buku bapak guru sama dengan buku saya” dan sebagainya. Dari contoh pernyataan tersebut, Nampak ada proses yang dilakukan oleh siswa yaitu proses “membandingkan”. Menurut Siskandar (1990:419) "pengukuran adalah membandingkan suatu ukuran dengan suatu ukuran yang lain yang sejenis(maksudnya panjang dibandingkan dengan panjang, luas dengan luas, berat dengan berat, dan sebagainya) sebagai patokan.” Hal ini sesuai dengan pendapat Van De Walle bahwa "pengukuran adalah bilangan yang mengindikasikan perbandingan antara sifat obyek (atau situasi atau kejadian) yang sedang diukur dan sifat yang sama dari satuan ukuran tertentu.”

\section{Pengukuran Waktu}

Waktu sedikit berbeda dengan sifat lain yang umumnya diukur di sekolah, karena tidak dapat dilihat atau dirasakan, dank arena lebih sulit bagi siswa untuk 
memahami satuan waktu atau cara waktu dicocokkan terhadap periode waktu atau situasi tertentu.

\section{a. Membandingkan Durasi}

Waktu dapat dipikirkan sebagai durasi kejadian dari awal sampai akhir. Seperti sifat lainnya, agar siswa cukup mengerti sifat waktu, mereka harus membuat perbandingan kejadian yang mempunyai durasi yang berbeda. Jika dua kejadian bermula pada waktu yang sama, kejadian dengan durasi yang lebih pendek, akan lebih cepat berakhir dari pada yang lebih panjang durasinya. Contohnya gasing mana yang berputar lebih lama? Namun bentuk perbandingan ini berfokus pada akhir durasi daripada durasi itu sendiri. Untuk memikirkan waktu sebagai sesuatu yang dapat diukur, akan membantu untuk membandingkan dua kejadian yang tidak bermula pada waktu yang sama. Hal ini membutuhkan beberapa bentuk pengukuran waktu untuk digunakan sejak awal.

Satuan informal waktu adalah durasi ayunan bandul terbuat dari bola tenis yang digantungkan dengan benang panjang dari atap. Benang panjang menghasilkan ayunan lambat, sehingga membuat perhitungan mudah dilakukan. Tetesan air keran yang terus menerus kedalam wadah kosong adalah pilihan lain. Ketinggian air pada wadah ditandai pada akhir periode. Ketika wadah bertanda dikosongkan dan digunakan untuk durasi kedua, dua tandanya dapat dibandingkan. Satu keuntungan dari metode tetesan air adalah tidak ada satuan yang perlu dihitung. Tugas-tugas sederhana lain yang mungkin dapat dibandingkan adalah sebagai berikut:

1) Menumpuk sepuluh blok satu per satu dan lalu memindahkannya satu per satu pula.

2) Mencetak huruf

3) Berjalan lambat sekitar jalan kecil tertentu

4) Membuat palang dari 15 kubus

Hanya satu siswa yang melakukan tiap tugas, jadi tidak akan ada kompetisi atau balapan. 
b. Membaca Jam

Instrument yang biasa digunakan untuk mengukur waktu adalah jam. Tetapi belajar untuk mengatakan waktu kurang berhubungan dengan pengukuran waktu dan lebih kepada kemampuan belajar membaca instrument tipe-piringan. Membaca jam adalah keahlian yang sulit untuk diajarkan.

c. Beberapa Kesulitan

Anak-anak biasanya pertama diajarkan untuk membaca satu jam, lalu setengah, dan seperempat jam, dan akhirnya interval 5 dan 1 menit. Pada tingkat awal rangkaian ini, anak-anak ditunjukkan jam yang diatur tepat setengah atau satu jam. Banyak anak yang bisa membaca jam 7.00 atau 2.30 tidak tahu apa-apa tentang jam 6.58 atau 2.33 .

Jam digital memudahkan siswa membaca waktu, tetapi kurang berkaitan dengan waktu. Untuk mengetahui bahwa pembacaan digital jam 7.58 adalah hamper jam 8.00, anak harus mengetahui ada 60 menit dalam satu jam, bahwa 58 dekat dengan 60, dan 2 menit bukanlah waktu yang lama. Konsep-konsep ini belum berkembang pada sebagian besar anak kelas satu dan banyak anak kelas dua. Jam analog (dengan tangan) menunjukkan waktu dekat tanpa perlu pemahaman angka besaratau bahkan beberapa banyak menit dalam 1 jam.

Pendekatan standar pembacaan jam mengesampingkan tindakan dan fungsi du jarum yang jelas berbeda. Jarum yang kecil menunjukkan waktu kirakira (jam terdekat) dan jarum yang besar menunjukkan waktu (menit) sebelum atau lebih dari 1 jam. Ketika kita melihat jarum jam, kita berfokus pada dimana jarum jam menunjuk. Dengan jarum menit, fokusnya adalah jarak yang telah dilalui jarum sekeliling jam atau jarak yang akan dilalui jarum untuk kembali ke angka teratas.

d. Pendekatan yang disarankan

Beberapa hal yang dapat membantu siswa memahami dan membaca jam, antara lain:

1) Mulai dengan jam satu jarum. Jam dengan hanya satu jarum dapat dibaca dengan cukup akurat. Gunakan banyak bahawa perkiraan:”sekarang kira-kira 
jam 7”. Sekarang jam 9 lebih sedikit.” Sekarang adalah pertengahan antara jam 2 dan jam 3.

2) Diskusikan apa yang terjadi dengan jarum besar ketika jarum kecilnya bergerak dari satu jam ke jam berikutnya. Ketika jarum besar menunjuk ke angka 12, jarum jam menunjuk tepat ke angka. Jika jarum jam berada diantara dua angka, di manakah letak jarum menitnya? Jika jarum jam sedikit lewat atau kurang dari satu jam (10 - 15 menit), di manakah letak jarum menitnya?

3) Gunakan dua jam yang sesungguhnya, satu dengan hanya jarum jam dan yang satu lagi dengan dua jarum. (patahkan jarum menitnya). Tutupi jam dua jarum. Secara berkala dalam satu hari, arahan perhatian pada jam satu-jarum. Diskusikan waktu dalam bahasa perkiraan. Minta siswa memprediksi dimana seharusnya letak jarum menit. Buka tutup jam dua jarum dan periksa.

4) Ajarkan mengenai waktu setelah satu jam dalam interval 5-menit. Setelah langkah 3 dimulai, bilang dalam interval lima melingkari jam. Daripada memprediksi bahwa jarum menit sedang menunjuk angka 4, dorong siswa untuk mengatakan itu sekitar 20 menit setelah satu jam. Ketika kemampuan mereka telah berkembang, anjurkan siswa pertama kali untuk melihat jarum kecil atau jarum jam untuk mempelajari kira-kira jam berapa sekarang. Dan lalu focus pada jarum menit untuk ketepatan.

5) Prediksi pembacaan jam pada jam digital ketika jam analog ditunjukkan, dan sebaliknya. Atur jam analog ketika ditunjukkan jam digital. Hal ini dapat dilakukan dengan jam satu jarum maupun dua jarum.

e. Konsep-konsep Terkait

Siswa juga perlu mempelajari detik, menit dan jam, dan mengembangkan beberapa konsep tentang berapa lama satuannya. Siswa dapat sengaja mencatat durasi kejadian panjang dan pendek dalam sehari. Pengukuran waktu kejadian kecil dengan durasi $1 / 2$ sampai 2 menit dapat menjadi kegiatan yang menyenangkan dan berguna. Acara TV dan iklan adalah standar yang bagus. Minta siswa mengukur waktu kejadian dalam kegiatan sehari-hari mereka. Seperti misalnya: menyikat gigi, makan malam, bersepeda ke sekolah, menghabiskan waktu dalam kelompok membaca. 
Ketika siswa lebih mempelajari angka dua digit, waktu setelah satu jam dapat juga dihubungkan dengan sisa waktu sebelum satu jam. Hal ini membantu tidak hanya untuk mengatakan waktu, tetapi juga untuk pemahaman bilangan. Catat bahwa dalam rangkaian yang disarankan, waktu setelah satu jam ditekankan hampir secara eksklusif. Waktu sebelum atau sampai satu jam dapat menyusul.

Kegiatan berikut dapat digunakan untuk membantu siswa pada kelas dua dan setelahnya, bahkan jika rangkaian kegiatan jam satu jarum belum dilakukan.

Jam Satu-Jarum

Siapkan satu halaman gambar jam. Pada tiap jam gambarkan jarum jam. Gambarkan penempatan jarum yang kira-kira menunjukkan satu seperempat jam, satu jam kurang seperempat, satu setengah jam dan beberapa yang sekitar satu jam. Tugas siswa adalah menulis waktu digital dan menggambar dimana jarum menit seharusnya berada pada setiap gambar jam.

Jam satu jarum adalah penilaian yang bagus dari kegiatan pembacaan jam. Jika siswa kelas tiga atau setelahnya mempunyai keselitan membaca jam, bekerja dengan jan satu-jarum seperti yang disarankan sebelumnya akan menawarkan pendekatan berbeda.

\section{f. Waktu Lewat}

Menentukan waktu yang telah lewat adalah keahlian yang dipersyaratkan oleh sebagian besar kurikulum Negara bagian. Hal ini juga merupakan keahlian yang sulit bagi siswa, khususnya pada periode waktu siang hari. Siswa harus mengetahui berapa banyak menit dalam satu jam. Hasil penilaian nasional menunjukkan bahwa hanya 58 \% siswa kelas 8 yang dapat mengatakan berapa banyak jam sama dengan 150 menit (Jones \& Arbaugh,2004). Jika diberikan waktu digital atau setelah satu jam, siswa harus mampu mengatakan berapa banyak menit ke jam berikutnya. Hal ini tentunya merupakan proses mental (dalam hati) kelipatan lima menit. Hindari meminta siswa menggunakan pensil dan kertas untuk mengurangi 25 dari 60.

Perhitungan waktu dari 8.45 sampai 11.45 adalah tugas multi langkah apa pun caranya. Mengawasi langkah pertengahan adalah hal yang sulit, sama seperti memutuskan hal apa yang akan dilakukan untuk pertama kalinya. Pada kasus ini, kita dapat menghitung jam dari 8.15 sampai 11.15 dan menambahkan 30 menit. 
Tetapi apakah akan kita lakukan jika titik-titik ujungnya adalah 8.45 dan 11.15 ? mengajukan metode atau algoritma tunggal tidak akan membantu.

Selanjutnya adalah tentang jam 00.00 - 12.00 dan jam 12.00 - 24.00. masalahnya bukan pada siswa tidak memahami apa yang terjadi pada jam di siang hari dan tengah malam, namun pada kesulitan membilang interval.

\section{Ilustrasi model sinektik dalam pembelajaran pengukuran waktu}

a. Strategi Pertama: menciptakan sesuatu yang baru

1) Mendeskripsikan kondisi saat ini

Guru meminta siswa untuk mendeskripsikan kegiatan sehari-hari, mulai dari bangun tidur sampai dengan tidur kembali, dengan menentukan masingmasing waktu atau jam berapa dari kegiatan tersebut.

(2) Analogi Langsung

Para siswa mengemukakan analogi langsung, salah satunya diseleksi dan selanjutnya dikembangkan. Misalnya dari beberapa kegiatan: bangun tidur jam 5.00, sarapan jam 5.30, pergi ke sekolah jam 6.30, dan seterusnya, maka ada yang ditentukan salah satu kegiatan yang dipilih sebagai salah satu yang diseleksi.

(3) Analogi Personal

Para siswa menjadi analogi yang diseleksinya pada fase kedua. Misalnya kegiatan bangun tidur jam 5.30 yang dipilih.

(4) Menekankan Pertentangan

Para siswa mengemukakan beberapa konflik dan dipilih salah satu. Misalnya kegiatan bangun tidur 5.30, sarapan jam 6.00, pergi ke sekolah 7.00, belajar di sekolah dari jam 7.30 sampai jam 15.30 .

(5) Analogi Langsung

Para siswa mengembangkan dan menyeleksi analogi langsung lainnya berdasarkan konflik tadi. Misalnya siswa menceritakan satu kegiatan bangun tidur yang tidak sesuai waktunya dengan yang seharusnya, maka akibatnya akan abagaimana?

(6) Meninjau Tugas Yang Sebenarnya 
Guru menyuruh para siswa meninjau kembali tugas atau masalah yang sebenarnya dan menggunakan analogi yang terakhir. Misalnya kegiatan bangun tidur yang paling baik adalah jam 5.00, agar tidak kesiangan, agar tidak terburu-buru, dan sebagainya.

b. Strategi Kedua: Memperkenalkan Keanehan

(1) Input tentang keadaan yang sebenarnya

Guru menyajikan informasi tentang topic yang baru. Misalnya: “Ayah bangun tidur jam 4.30.kemudian pergi ke kantor jam 6.30. di Kantor, Ayah bekerja sampai jam 14.30. berapa jam dan berapa menit kegiatan yang dilakukan oleh Ayah?

(2) Analogi Langsung

Guru mengusulkan analogi langsung dan menyuruh siswa menjabarkannya. Misalnya tuliskan contoh kejadian kegiatan yang lain dari kegiatan sehari-hari, seperti yang dicontohkan guru.

(3) Analogi Personal

Guru menyuruh siswa menjadi analogi langsung. Misalnya seandainya seluruh kegiatan yang dilakukan Ayah masing-masing berbeda 15 menit, maka kegiatan apa yang akan terjadi, dan berapa jumlah seluruh menit dan jamnya ?

(4) Membedakan Analogi

Para siswa menjelaskan dan menerangkan kesamaan antara materi yang baru dengan analogi langsung. Misalnya jelaskan kesamaan dan perbedaan kegiatan yang dicontohkan guru dengan kegiatan yang dicontohkan siswa!

(5) Menjelaskan Perbedaan

Para siswa menjelaskan mana analogi-analogi yang tidak sesuai?

(6) Penjelajahan

Para siswa menjelajahi kembali kebenaran topic dengan batasan-batasan mereka.

(7) Membangkitkan Analogi

Para siswa memberikan analogi sendiri secara langsung dan menjelajahi persamaan dan perbedaannya. 


\section{DAFTAR PUSTAKA}

Dahlan M.D. (1990). Beberapa Alternatif Interaksi Belajar Mengajar ModelModel Mengajar. Bandung: Dipenogoro.

Joyce. B. (2009). Models Of Teaching Model-Model Pengajaran. Yogyakarta: Kebudayaan Proyek Penataran Guru SD Setara D-II.

Moedjiono. (1992/1993). Strategi Belajar Mengajar. Jakarta: Departemen Pendidikan dan Kebudayaan Dirjen Dikti PPTK.

Mulyana. (2001). Rahasia Matematika Cara Pintas Mencapai Tingkat Kemahiran. Surabaya: Edutama Mulia..

Pustaka Pelajar.

Siskandar. (1990). Pendidikan Matematika I. Jakarta: Departemen Pendidikan dan

Sumantr M. (1998/1999). Strategi Belajar Mengajar. Jakarta: Departemen Pendidikan dan Kebudayaan Dirjen Dikti PPGSD.

Van De Walle. John A. (2002). Sekolah Dasar dan Menengah Matematika Pengembangan Pengajaran. Jakarta: Erlangga.

*) Deti Rostika adalah dosen PGSD UPI Kampus Cibiru 